\title{
Economic Value-Added Creation by Optimizing Capital Structure in Project Finance
}

\author{
Bryan Charisma and Encep Amir \\ PT PLN (Persero) Indonesia (Electricity Company)
}

\begin{tabular}{l} 
ARTICLE INFO \\
\hline Keywords: \\
Economic Value Added \\
Project Finance \\
NOPAT \\
Balance sheet \\
WACC \\
ROIC
\end{tabular}

\section{ARTICLE INFO}

Keywords:

Economic Value Added

NOPAT

ROIC

\begin{abstract}
Infrastructure Projects are large investment by the public and/or private sector that required enormous financial resource commitment to build physical asset and facilities needed for economic development so that the company need project financing to support with. Project finance is based on debt repayment from project companies' revenue and not on the sponsors or the developer's balance sheet, so the project companies should assure the cash flow is sufficient for debt repayment and dividend payment. Beside that investors still have to analyze the value created in that project with highest positive Economic Value Added. Net Operating Profit After Tax (NOPAT) need to cover cost of invested capital to create value so that the ratio of NOPAT to total Project Cost (Return on Invested Capital) is should be more than the weighted average cost of capital (WACC). The capital structure doesn't have an optimum weight and cost as long as the Return on Invested Capital (ROIC) higher than WACC.
\end{abstract}

\section{Introduction}

\subsection{Electricity Supply Acceleration Program}

In 2016 Government of Indonesia commit to fulfill the electricity demand equitably and prevail in Indonesia, Government of Indonesia ("GOI") produce the Presidential Regulation ("Perpres") of The Republic of Indonesia Number 4/2016 regarding The Electricity Infrastructure Acceleration that the infrastructure of electricity should develop generation that reach $35.000 \mathrm{MW}$ and $46.000 \mathrm{~km}$ for the Transmission and also prioritize the use of renewable energy to support the to reduce global warming. This Commitment also represent in Electricity Supply Business Plan 2017-2025, 2018-2026, and 2019-2027. Concerning the Electricity Infrastructure Acceleration, GOI intensify that commitment by developing the Committee for Acceleration of Priority Infrastructure Delivery (KPPIP) regulated in Perpres Number 122/2016 amendment from Number 75/2014 to overcome infrastructure deficit in previous year and reach the economic growth. Regulation of the President of the Republic of Indonesia Number 5 of 2010 Regarding the National Medium Term-Development Plan (RPJMN) 2015 - 2019 is arrange with the emphasizing in development acceleration. Based on Perpres 75 of 2014 the KPPIP has 6 (six) priority mandate encompass of (1) Determining and controlling the policy and strategy of priority infrastructure supply acceleration, (2) Managing and monitoring the implementation of the priority infrastructure supply acceleration, (3) Facilitating the improvement of state apparatus associated with the priority infrastructure supply acceleration, (4) Determining quality standard of feasibility evaluation, (5) Facilitating the preparation of priority infrastructure, (6) Debottlenecking the priority infrastructure problem.

\footnotetext{
* Corresponding Author E-Mail Address: charismabryan@gmail.com 
Table 1.

KPPIP $I^{\text {st }}$ Semester in 2019 Report

\begin{tabular}{cccc}
\hline No & Project & $\begin{array}{c}\text { Investment Cost } \\
(\text { Rp billion })\end{array}$ & Financing Scheme \\
\hline 1 & Street and Bridge & 336.838 & Loan and Government Fund \\
2 & Transportation & 278.995 & Loan and Government Fund \\
3 & Telecommunication & 5.840 & Loan and Government Fund \\
4 & Electricity & 612.020 & Loan and Government Fund \\
5 & Energy & 1.188 .848 & Loan and Government Fund \\
6 & Water and Sanitation & 6.031 & Loan and Government Fund \\
7 & Waste Energy & 19.478 & Loan and Government Fund \\
& Total & $\mathbf{2 . 4 4 8 . 0 5 0}$ & \\
\hline
\end{tabular}

Table 1. Explain about the priority of infrastructure project in Indonesia in the KPPIP Report of $1^{\text {st }}$ semester in 2019, the amount of total cost of project estimated around Rp2.488,05 trillion or equivalent to US\$ 181.3 billion (rate Rp.13.500) encompass of 7 (seven) priority project of Street and Bridge, Transportation, Telecommunication, Electricity, Energy, Water and Sanitation, and Waste Energy. It is an enormous number of infrastructure cost that should be fulfilled for GOI with a limited time, Strategy and Policy has been formed to support these matters, including Fiscal reformation, availability payment, viability gap fund, project preparation development, and tax holiday, this time one of the biggest matters is viability gap fund. GOI also produce several regulations, Economic Policy Packet, to create a conducive investment ecosystem. Indonesia Government also develop strategy to overcome viability gap fund by project financing. Project finance is expected to be executed as soon as possible and with the compliance concept.

\subsection{Project Finance}

Project finance is not a stand-alone function based on contract finance or legal engineering as it being treated in the current paradigm. It has been developed to advanced levels for the primary purpose of facilitating new project and business development activities with the nonrecourse aspect as an ancillary factor. It should be treated as a part of new business development with its focus on striving to maintain or obtain competitive advantage. A key objective of project finance is to minimize or avoid uncertainty. Unlike asset-based finance, where the asset value determines financing, the adequacy of project cash flow is the foundation of funding. Since infrastructure project have different types of assets and objectives, capital requirement, and risks, they get different benefit from project financing.

Project-finance structure differ between various industry sectors and from deal to deal, since each project has its own unique characteristic. So, the principles of the project finance are: “..finite life project that the project company's physical assets are likely to be worth much less than the debt if they are sold off after a default on the financing-and in the projects involving public infrastructure they cannot be sold anyway which has high ratio of debt to equity ("leverage of gearing")- roughly speaking, project finance debt may cover 70-90\% of the capital cost of the project.."(Yescombe, E.R. Project Finance. Wiley, 2009)

Hence, project finance differs from corporate finance, where loans are primarily lent against a company's balance sheet and financial projections extrapolated from its past cash flow and profit record and when project fails, corporate lenders can still reasonably expect to be repaid. Structure of a project financing usually has two elements, first is equity, provided by investors in the project and project finance-based debt, provided by one or more groups of lenders.

The project-finance debt has first call on the project's net operating cash flow; the investors' return is thus more dependent on the success of the project. So as the investors are taking a 
higher risk, they expect a higher return on their investment, and the reverse is true for lenders. A nexus of contracts signed by the Project Company provide support for the finance. A 'Project Agreement' is often at the center of this contractual structure. This may take two main forms: either an 'Offtake Contract', under which the product produced by the project will be sold on a long-term pricing formula to an 'Offtaker' or a contract with a central government department, regional or state government, county or municipality, or another public agency ('Contracting Authority' will be used to cover all of these), which gives the Project Company the right to construct the project and earn revenues from it.

Alternatively, the Project Company may sell its production in commodity markets (which may apply, for example, to power or natural-resources projects) or have a license to operate under the terms of general legislation for the industry sector (e.g., a privatized port or airport, or a mobile-phone network), in both cases without an Offtake Contract or Project Agreement, as discussed further below. The Project Company usually enters into 'Sub-Contracts', which provide support for the project finance, particularly by transferring risks from the Project Company to other parties, and which also form part of the lenders' security package.

These are projects where there is an input at one end of the project, which goes through a process within the project, and emerges as an output such as; thermal power generation, water treatment, waste incineration; and LNG (liquid natural gas) terminal. Typical basic elements of this type of project, using coal-fired power plant as an example, are set out in figure 1.2. In this case the Project Agreement is in the form of a type of Offtake Contract, namely a Power Purchase Agreement ('PPA'), under which an electricitydistribution company purchases the project's output, i.e., electricity, based on an agreed tariff. This Offtaker may be either a public- or private-sector entity, depending on whether the electricity industry is privatized in the country concerned and the project company take the supporting agreement to subcontractor which are an Engineering Procurement and Construction Contract (EPC Contractor) for design and construction of the power plant, Coal-Supply Contract, in this case a Coal-Supply Agreement under which the coal to fuel the plant is supplied and an Operation and Maintenance Contract ('O\&M Contract') with an experienced power-plant operator. Figure 1.2 explain a lot about the stakeholder or parties that belong to the project, so that the investor should put much attention about every parties competencies' and capabilities to join to the project. Not only investor but also lender usually take a deep-dive understanding in parties joined in this project to make this project successfully at the terms of financing-service tenure.

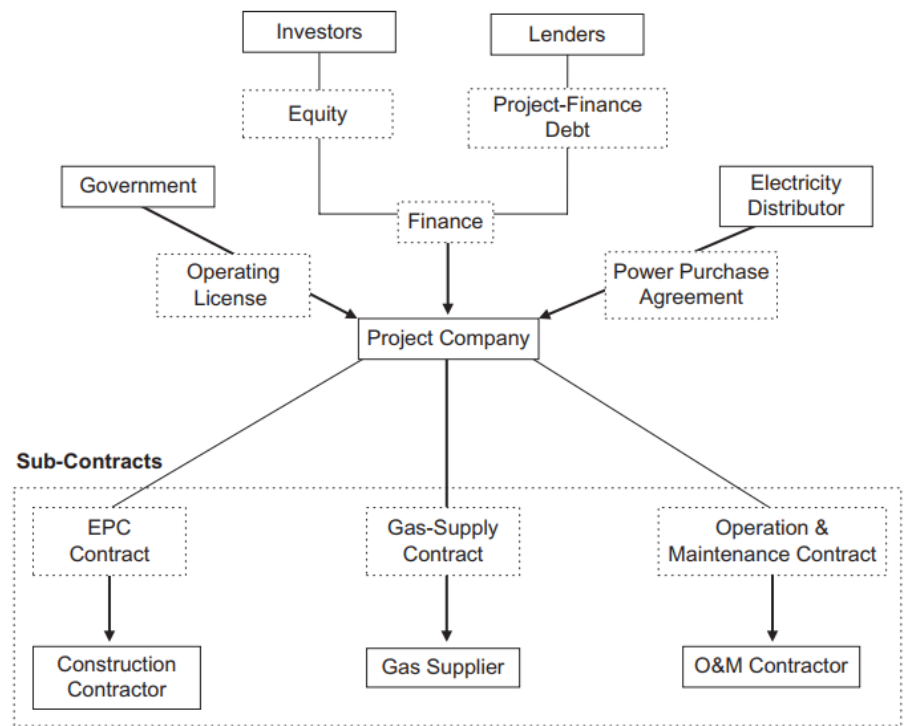

Figure 1.2. PPA Contract Structure with Project Finance

Source: Yescombe, E.R. Principles of Project Finance. Wiley, 2016 
According to the fulfillment of the total investment cost of total project reach the $\mathrm{Rp} 2.448,05$ trillion in Indonesia for the infrastructure project. Project finance has an important role in financing scheme to make this project happened because such large investment could not be supported with corporate finance scheme. Beside the adequacy of financing requirement, investor should aware of their capital in the project and calculate precisely about the rate of required return to shareholder. Net present value ("NPV") and Internal Rate of Return ("IRR") is the basic effectively parameter to calculate the magnitude of return generated from the project as a percentage of investor's equity. NPV is equal to value of the project cash flows discounted at the cost at the cost of capital. The NPV tells us how much a project contributes to shareholder wealth; the larger the NPV, the more value the project adds. IRR is equal to the discount rate that forces the Present Value of its inflows to equal its cost. The is equivalent to forcing the NPV to equal zero. The IRR is an estimate of the project's rate of return, if this return exceeds the cost the funds used to finance the project, the difference will be an additional return (in a sense a "bonus") that goes to the firm's stockholders and cause the stock value. Project $\mathrm{X}$ has an estimated return of $15 \%$ versus a $10 \%$ cost of capital, so it provides an additional return of 5\% above its cost of capital. On the other hand, if the IRR is less than cost of capital, stockholders must make up the shortfall, which will hurt the stock value. Both IRR dan NPV use Cost of Capital to generate the result, NPV use the Cost of Capital as denominator for its serial cashflow and IRR use Cost of Capital as comparison to know about the "bonus" that goes to the firm's stockholders.

Project company need source of capital to develop project, financial management fundamental classifies the source of capital into two in general, first is Equity, second is Debt. Each of capital has cost to give to capital provider, Cost of Equity is equal to capital charge to equity provider and cost of debt is equal to capital charge to debt provider. So, if the project could make required return exceed the cost of capital, this project could create the value to all capital provider. The average total of cost of capital is called Weighted Average Cost of Capital ("WACC"). When calculating the WACC, the most concern is the capital that must be provided by investors - interest bearing debt, preferred stock, and common equity. The lowest WACC generate the highest value of NPV and the Capital component as explained before explain that combination in cost of capital is formed by cost of debt and cost of equity. Generally, Cost of debt is cheaper than cost of equity because of the risk that should be taken by equity provider so that the weight of debt is needed more than weight of equity. This is the one of the reasons why project finance is existing and fast to accelerate the execution of the infrastructure project and mostly used by more portion of debt in their capital structure to lowering their WACC and produce higher NPV and IRR.

At some point, however, the combination of increasing cost of debt and equity would begin to raise the overall WACC and lower the NPV or the firm's value. Some Empirical test, notably by showed that leverage did indeed impact the firm's overall cost of capital. Two and a half decades later, reflected again on the Modigliani \& Miller capital structure argument that increasing as a firm's leverage cause probability of bankruptcy also increases, and if the cost of bankruptcy is significant, the firm's value will fall when the marginal increases in the expected value of the tax benefit from debt is overwhelmed by the expected present value of distress cost. Figure 1.2.1 shows that financial distress and agency cost are the major factors accounting for the difference between the so-called pure M\&M value of the firm (with the tax subsidy) and the revised traditionalist value of the firm. The net result is an optimum point on the debt/value axis ( $\left.\mathrm{D}^{*}\right)$ at which at the firm's value is maximized. 


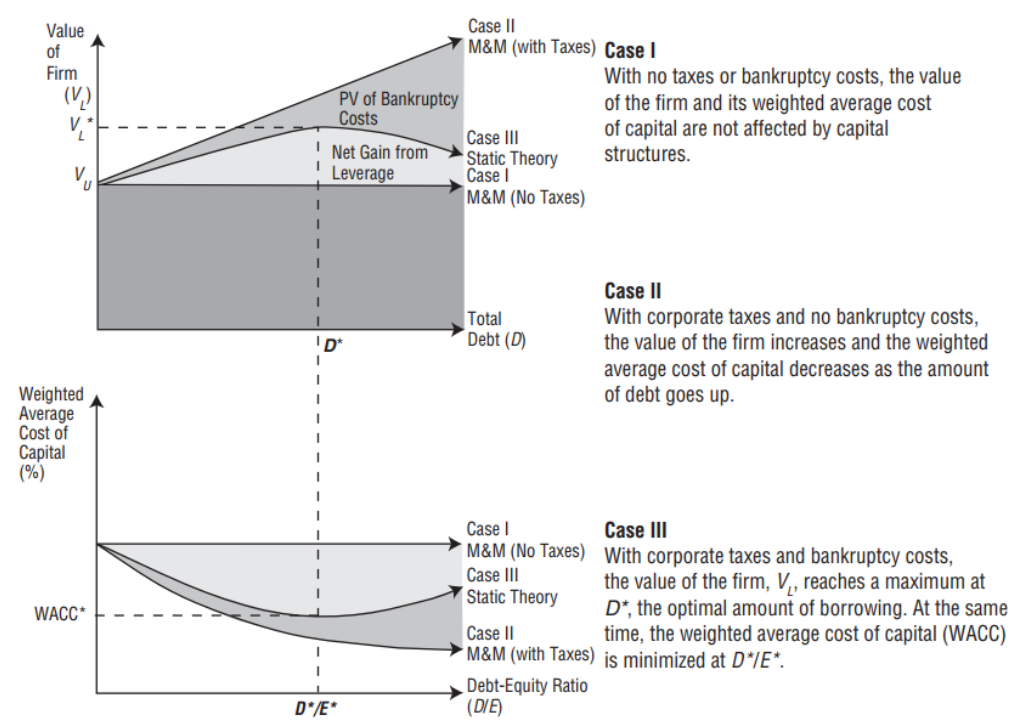

Figure 1.2.1 Net Effects of Leverage of Firm Value: M\&M and Altman (1984)

Source: Edward, Altman, and Edith Hotchkiss. Corporate Financial Distress and Bankruptcy. Wiley, 2006

Project finance is not so different from corporate finance in perspective of profitability, only for its limitation in tenure, it takes commonly for 25 years for electricity project so that the debt provider cannot do the restructuring or do the refinancing the loan when it come worst condition. Debt holder put their much attention in how the project company generate the profit in sustainable way. Profit could classify into two different kind of name, first is accounting profit and second is economic profit. Accounting profit is the difference between total monetary revenue and total monetary cost, and is computed by using Generally Accepted Accounting Principle (GAAP), Economic Profit measure the value created by the company when the company could get the "bonus" from the spread between the NOPLAT and the cost of fund invested from capital provided ("Cost of Invested Capital"), another name of economic profit is Economic Value Added ("EVA"). EVA is not just a performance measure. It is that, but it is a lot more. EVA has an application to every facet of corporate performance management. It is a technique for improving the planning process, optimizing the investment and determining strategies. Bennet (2013) from the book of "Best Practice EVA" explain that EVA is sales less operating cost less the full cost of financing the asset from capital provider. It consolidates income efficiency and asset management into one net profit score. From this explanation, here is the example of EVA's calculation:

\begin{tabular}{lll}
\hline Sales & $\$ 1,250$ & Customer Satisfaction, Growth, and Innovation \\
Operating Cost & $\$ 1,100$ & Pricing Power, Purchasing Power, Efficiency \\
NOPAT & $\$ 150$ & Net Operating After Tax \\
Capital Cost & $10 \%$ x $\$ 1,000$ & Working Capital Turn, Plant Productivity \\
$=$ EVA & $\$ 50$ & \\
\hline
\end{tabular}

Figure 1.4 Formula of Economic Value Added

Source: G. Bennet, Stewart. The EVA Challenge_Implementing Value Added Change in an Organization. Mcgrawhill, 2016

The simple sample company shown above-let's call it EnergyCo-generates $\$ 1,250$ in sales with $\$ 1,100$ of operating costs, leaving a $\$ 150$ remainder called net operating profit after taxes (NOPAT). NOPAT is a resting point partway down the EVA schedule. It is the firm's 
operating profit, net of depreciation and amortization to make it sustainable, and after taxes on the operating profit are deducted. With NOPAT now defend, we can say that EVA is equal to NOPAT less a charge for capital. When EnergyCo could make $\$ 50$ of EVA, it means that EnergyCo could give the shareholder's value of $\$ 50$ because of the operating activities generates value more than the cost that should be paid to the capital holder. From this explanation, we would like to see about the value that the project company could give to shareholders in project finance in this article, and hopefully at the end we have the conclusion if there is an EVA from the project finance scheme in infrastructure's project in Indonesia.

\section{Method}

According to 35 GW's programs included in Perpres Number 04/2016 about Electricity Infrastructure Acceleration Program ("Acceleration Program") and the Electricity Supply Business Plan (RUPTL) 2019 - 2028 that are needed to fulfill electricity demand in Indonesia, this paper classifies the power generation project using capacity range. It divides into 3 (three) range from $10-200 \mathrm{MW}, 200-700 \mathrm{MW}$ and >700 MW. From RUPTL $2019-$ $2028 \mathrm{GOI}$ is directed to fulfill the load growth and load deficit in certain areas. The growth of power generation capacity is also intended to enhance the electricity supply reliability by using the energy resource and renewables. This paper mention 3 (three) different projects as a evaluation basis and sample, first project is called Kaltim 5, a Mine Mouth Coal Fired Power Plant with capacity $200 \mathrm{MW}$, second project is called Jawa 3, a Combined Cycle Power Plant with capacity $800 \mathrm{MW}$ and third project is called Merauke 2, a Mobile Power Plant with capacity 20 MW. All of those projects are mentioned in RUPTL 2019-2028 and part of Acceleration Program projects for Indonesia according to fulfill the electrification ratio.

The structure of the method is using the case study by 3 (three) projects as proxy for the range of capacity in RUPTL. Those projects are evaluated with the border of analysis variable to be determined as assumption. It will be a boundary and to ease the calculation and get the result with same parameter in order to produce the reasonable and obvious result not to deviate excessively. After determining the assumption of the projects, the methods continue to calculate NOPAT and EVA Analysis, ROIC Calculation and the solvency ratio analysis in order to get the result that could give the understanding about how the capital structure from project finance could create positive or negative EVA.

\subsection{General Assumption}

Assumption is necessary to specify the boundary of analysis point of sight and generating the result, there are a lot of variables in to be used such as: Project Cost, Capital Structure, Cost of Capital, Equivalent Availability Period (EAF) etc. Project Cost and cost of capital use data of United States Energy Information Administration (EIA) as mentioned in table 2.1 by calculating the Levelized Cost of Electricity (LCOE). Table 2.1, table 2.1.2 and table 2.1.2 are used to estimate the total investment cost for the project sample for this paper. Table 2.1.2 is the description of the implemented project for coal fired power plant in order to get imminent estimation based on KPPIP report of $1^{\text {st }}$ semester of 2019.

Table 2.1

Estimated Levelized Cost of Electricity for New Generation Resource

\begin{tabular}{|c|c|c|c|c|c|c|c|c|}
\hline Plant type & $\begin{array}{l}\text { Capacity } \\
\text { Factor }\end{array}$ & $\begin{array}{c}\text { Levelized } \\
\text { Capital }\end{array}$ & $\begin{array}{l}\text { Levelized } \\
\text { Fixed O\&M }\end{array}$ & $\begin{array}{c}\text { Levelized } \\
\text { Variable } \\
\text { O\&M } \\
\end{array}$ & $\begin{array}{c}\text { Levelized } \\
\text { Transmission } \\
\text { Cost } \\
\end{array}$ & $\begin{array}{c}\text { Total } \\
\text { System } \\
\text { LCOE } \\
\end{array}$ & $\begin{array}{l}\text { Levelized } \\
\text { Tax Credit }\end{array}$ & $\begin{array}{c}\text { Total } \\
\text { LCOE incl } \\
\text { Credit }\end{array}$ \\
\hline $\begin{array}{c}\text { Dispatchable Technologies } \\
\text { Coal with } 90 \% \text { CCS }\end{array}$ & 85 & 50.2 & 11.2 & 36.0 & 1.1 & 98.6 & N/A & 98.6 \\
\hline Coal with $90 \%$ CCS & 85 & 50.2 & 11.2 & 36.0 & 1.1 & 98.6 & N/A & 98.6 \\
\hline
\end{tabular}

Source: US. Energy Information Administration (EIA). Levelized Cost and Levelized New Generation Cost. 2020 
Table 2.1.1

Financial Parameter and Assumption in Electricity Capacity Planning

\begin{tabular}{lllll} 
& Variables & & Parameters & \\
\hline 1. & Debt fraction & $60 \%$ & Exogenous & Fixed \\
\hline & Cost of debt: & & Endogenous & Varied \\
\hline 2. & Industrial Baa bond rate & & Endogenous & Varied \\
\hline & Cost of equity: Capital asset pricing model & & Endogenous & Varied \\
\hline 3. & Risk-free rate: 10 -year Treasury note rate & & Endogenous & Varied \\
4. & Market risk premium & $5.75 \%$ & Exogenous & Fixed \\
\hline 5. & Equity beta & 1.25 & Exogenous & Fixed \\
\hline 6. & Corporate tax rates ${ }^{36}$ & $38 \%$ & Exogenous & Fixed \\
\hline & $\quad$ Nominal WACC & & Endogenous & Varied \\
\hline
\end{tabular}

Source: US. Energy Information Administration (EIA). Levelized Cost and Levelized New Generation Cost. 2020

Table 2.1.2

KPPIP Priority Electricity Infrastructure Program

\begin{tabular}{|c|c|c|c|c|c|c|c|c|}
\hline $\begin{array}{l}\text { Project } \\
\text { Name }\end{array}$ & Type & $\begin{array}{l}\text { Funding } \\
\text { Scheme }\end{array}$ & Location & $\begin{array}{l}\text { Project } \\
\text { Owner }\end{array}$ & $\begin{array}{l}\text { Investment } \\
\text { Value } \\
\text { (Rp million) }\end{array}$ & $\begin{array}{l}\text { Investment } \\
\text { Value } \\
\text { (US\$) }\end{array}$ & $\begin{array}{c}\text { Capacity } \\
\text { (MW) }\end{array}$ & $\begin{array}{c}\text { Investment } \\
\text { Cost } \\
\text { (US\$/Kw) }\end{array}$ \\
\hline Indramayu & $\begin{array}{l}\text { Coal Fired } \\
\text { Power Plant }\end{array}$ & $\begin{array}{l}\text { State } \\
\text { Budget }\end{array}$ & Indramayu & PT PLN & 29.565 .000 & $2,111,785,714$ & 1.000 & 2.112 \\
\hline Batang & $\begin{array}{l}\text { Coal Fired } \\
\text { Power Plant }\end{array}$ & PPP & $\begin{array}{c}\text { Central } \\
\text { Java }\end{array}$ & PT PLN & 56.700 .000 & 4.050 .000 .000 & 2.000 & 2.025 \\
\hline Average & & & & & & & & 2.068 \\
\hline
\end{tabular}

Source: KPPIP $1^{\text {st }}$ Semester of 2019 Report

Based on table 2.1 and cost of capital as a proxy for evaluation basis for the calculation, which has been calculated to this paper to set the boundary and generalized all the cost of capital. Electricity Capacity Planning (ECP) submodule of the National Energy Modelling System (NEMS) set debt to equity ratio 60 to 40, from Annual Energy Outlook 2019 reported by EIA, it suggests a debt fraction $60 \%$ is more commonly observed with recent project financing. It should be noted that the analysis is focused on company-level and some subsidiary-level analysis and not at project-level analysis that would give better insight project economics that may vary by location or technology for a given company. Term loan is determined 12 year and after debt service is over, capital structure used by the project is full equity (100\% equity). Using that basis of analysis table 2.1.2 mention a comprehensive picture of all projects assumption used in this paper to generate result.

Table 2.1.2

Projects General Assumption

\begin{tabular}{cccccccccc}
\hline $\begin{array}{c}\text { Project } \\
\text { Name }\end{array}$ & Type & $\begin{array}{c}\text { Capacity } \\
(\mathbf{M W})\end{array}$ & $\begin{array}{c}\text { Project } \\
\text { Cost } \\
\text { (US\$) }\end{array}$ & $\begin{array}{c}\text { Capacity } \\
\text { Factor }\end{array}$ & $\begin{array}{c}\text { LCOE } \\
\text { Capital Cost } \\
\text { (Mwh) }\end{array}$ & $\begin{array}{c}\text { Operati } \\
\text { ng year }\end{array}$ & $\begin{array}{c}\text { Debt to } \\
\text { Equity Ratio }\end{array}$ & $\begin{array}{c}\text { Capital Cost } \\
\text { WACC } \\
\text { Recovery } \\
\text { (cUSD/Kwh) }\end{array}$ \\
\hline Kaltim-5 & Coal Fired & 200 & 413.600 .000 & $85 \%$ & 51.3 & 25 & $60: 40$ & $7,11 \%$ \\
Jawa-3 & Combine Cycle & 800 & 666.044 .306 & $87 \%$ & 10.4 & 20 & $60: 40$ & $7,11 \%$ & 1.308 \\
Merauke-2 & Gas Engine & 20 & 16.055 .829 & $30 \%$ & 29.8 & 20 & $60: 40$ & $7,11 \%$ & 3.864 \\
\hline
\end{tabular}

Source: Author's Compilation

\subsection{NOPAT and EVA Analysis}

This second sequence analyze the NOPAT and EVA in the Project by using financial model, NOPAT is calculated as the sales of the electricity minus cost of production deducted by the adjusted tax, then the EVA is calculated as the NOPAT times the capital charges, in electricity project, operating profit is generated from component a tariff-known as capital cost recovery. This paper used capital cost recovery factor to determine the investment cost based on several variables such as WACC, inflation rate, expected return above WACC and project economic life. Figure 2.2 describe about how the operating profit or component a is calculated and also about the assumption which derived the result and component a is a 
surplus from the subtraction of cost to the revenue and used to cover interest expense and tax as described in figure 2.2.1.

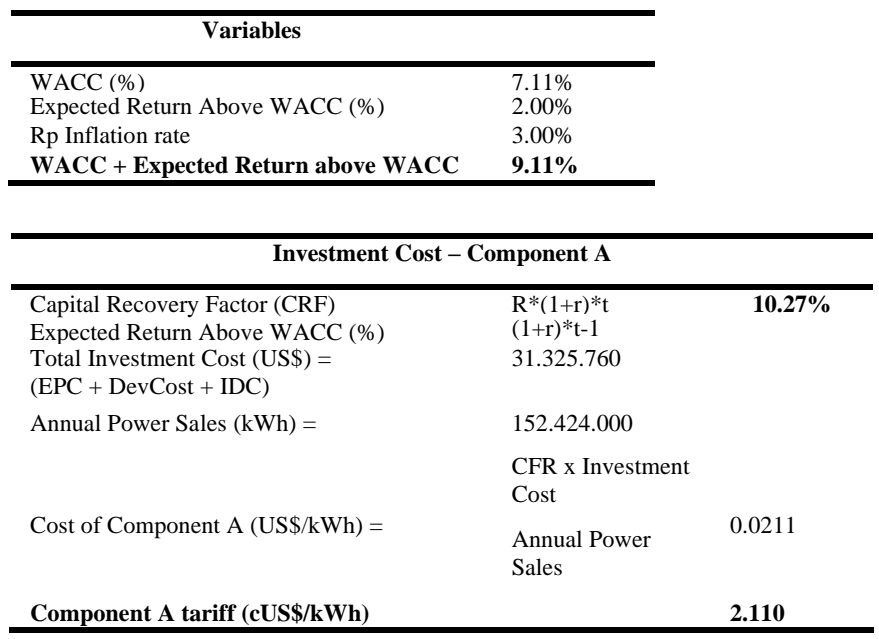

Figure 2.2 Component A Calculation as Operating Profit

Source: Author's Compilation

EVA is calculated by subtracting the cost of capital in terms of dollar amount from the operating profit after tax (NOPAT). Figure 2.2.1 explain about the calculation of EVA as a formula to specify the value creation from projects or business performance. EVA is generated from the surplus from ROIC to WACC and NOPAT to capital charge.

Economic Value Added = Invested Capital x (ROIC - WACC $)$
Or
Economic Value added = Net Operating Profit After Tax - Capital Charge

Figure 2.2.1 Economic Value Added Equation

Source: Koller, Tim. Marc Goedhart. Valuation_Measuring and Managing Companies Value. Wiley, 2015

EVA result is calculated annually discounting to capital structure on the calculating year to have a present value of EVA. Figure 2.2.2 gives the insight of the comparison how a project could give value from positive EVA or vice versa. the result is determined from the capital cost and operating cost that should be covered from net the profitability of the project.

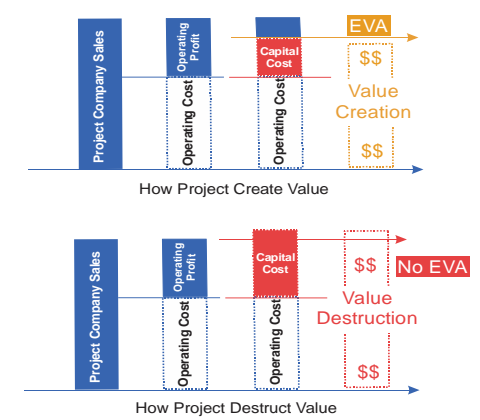

Figure 2.2.3 Comparison of Value Creation Project

Source: Author's Compilation

\subsection{ROIC Analysis}

ROIC Analysis in this project takes variety of project life calculation in each year about the ratio of NOPAT to Invested Capital. Invested Capital are the capital used in the company or the project to generate return which divide into working capital, property plant and equipment, and other capital related generating operation activities in company. ROIC is expressed in percent of NOPAT to Invested Capital, 1\% of ROIC means that the Capital 
Invested in the company could produce $1 \%$ operating profit to the company. Figure 2.3 describe the principle to help the managers decide which investment will create most value for shareholders in the long term. These principles also help investors assess the potential value of companies they might consider investing in that is caused from ROIC, cash flows, and value and it introduce the way managers can use these relationships to decide among different investment or strategies.

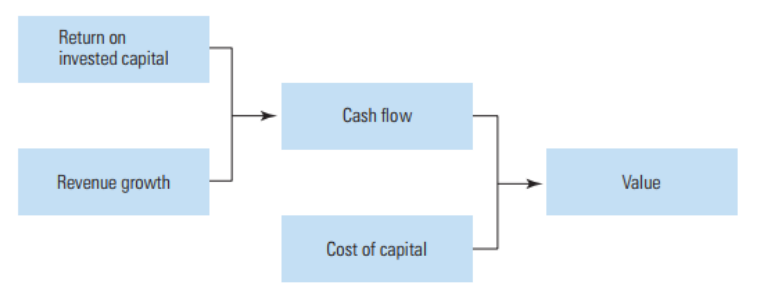

Figure 2.2 ROIC and Growth Relationship

Source: Koller,Tim. Marc Goedhart. Valuation_Measuring and Managing Companies Value. Wiley, 2015

\subsection{Solvency Ratio Analysis}

Solvency ratio measurement is financial ratio that has been used to detect the level of solvability of the company in order to know the impact from variety the capital structure composition. This ratio is a tool for turning data contained in financial statement into information used by investor, manager and executives to better understand what is happening in a company from its capacity to cover the exposures of debt. The increase of leverage used in project finance from the cost of capital optimization side will increase the firm value otherwise the solvency ratio side to give the signal to company for the risk produced from the addition of leverage, this paper use Interest Coverage Ratio to indicates company's ability to pay interest on its outstanding debt and to what extent operating's income can decline before the company is unable to cover its annual expenses and also strengthens the statement as mentioned in figure 2.4 which positive EVA could not increase the risk level of financial distress but if the negative EVA is generated, Solvency Ratio use to emphasize the value destruction due to the higher portion of debt.

\footnotetext{
Interest Coverage $=$ EBIT / Interest Expense

Figure 2.4 Interest Coverage Ratio Calculation

Source: Ritz, Michael, Albert Pizzica. Financial Ratios for Executives. Wiley, 2015
}

\subsection{Sensitivity Analysis}

Additional measure of sensitivity analysis is considered necessary for capturing unpredictable scenario that could be happened in the future for the projects. Sensitivity analysis in this paper use to detect the impact from the change of certain variables, this paper only use DER as the only variable which determined important to affect the result because of its magnitude cause significant impact to WACC calculation. Figure 2.5 describe DER variables which shift from point of evaluation basis of DER $(60 \% 40 \%)$.

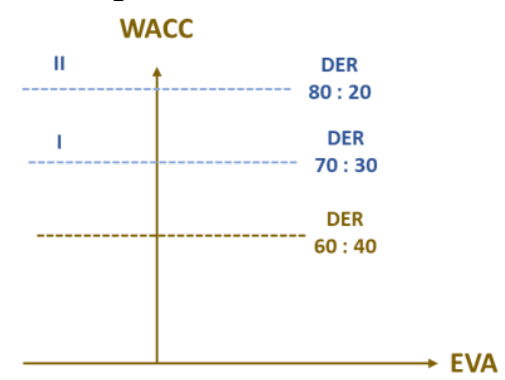

Figure 2.5 Sensitivity Analysis of Debt to Equity

Source: Author's Compilation 


\section{Result}

The result will examine every point that mentioned from method, so the result will give the view about NOPAT and EVA, ROIC, Solvency Ratio and also Sensitivity Analysis to assure about the magnitude of capital structure predispose the EVA result. At the end of the result of this paper, the reader could see about how the Projects produce the EVA and the correlation to level of financial distress generated from the increasing of debt exposure.

\subsection{NOPAT and EVA}

\begin{tabular}{|c|c|c|c|c|c|c|c|c|c|c|c|c|c|c|c|c|c|c|}
\hline \multicolumn{11}{|c|}{ EVA Calculation } & \multicolumn{6}{|c|}{ NPVIRR Calculation } & \multirow[b]{2}{*}{$\begin{array}{c}\text { FCFE } \\
\text { (USD 000,000) }\end{array}$} & \multirow[b]{2}{*}{$\begin{array}{l}\text { Discounted FCFE } \\
\text { (USD 000) }\end{array}$} \\
\hline \multicolumn{2}{|c|}{ OPERATING YEAR } & \multirow{2}{*}{$\begin{array}{c}\begin{array}{c}\text { NOPAT } \\
\text { (USD 000) }\end{array} \\
28,014,591.42\end{array}$} & \multirow{2}{*}{$\begin{array}{r}\begin{array}{r}\text { Total Invested } \\
\text { Copital } \\
\text { (USD 000,000) }\end{array} \\
394,718,813\end{array}$} & \multirow{2}{*}{$\begin{array}{l}\text { Debt } \\
\text { Ratio } \\
\text { (\%) } \\
60 \%\end{array}$} & \multirow{2}{*}{$\begin{array}{l}\text { Equity } \\
\text { Ratio } \\
\text { (\%) } \\
40 \%\end{array}$} & \multirow{2}{*}{$\begin{array}{c}\begin{array}{c}\text { RoIC } \\
(\%)\end{array} \\
7.10 \%\end{array}$} & \multirow{2}{*}{$\begin{array}{r}\begin{array}{c}\text { Cost of } \\
\text { Equity } \\
\text { (\%) }\end{array} \\
13.39 \%\end{array}$} & \multirow{2}{*}{$\begin{array}{c}\begin{array}{c}\text { WACC } \\
(\%)\end{array} \\
7.11 \%\end{array}$} & \multirow{2}{*}{$\begin{array}{l}\text { EVA } \\
(\%) \\
0.0 \%\end{array}$} & \multirow{2}{*}{$\begin{array}{l}\begin{array}{c}\text { Discounted EVA } \\
\text { (USD 000) }\end{array} \\
(46,602.73)\end{array}$} & \multirow{2}{*}{$\begin{array}{l}\text { WACC } \\
7.11 \% \quad 1\end{array}$} & \multirow{2}{*}{$\begin{array}{c}\begin{array}{c}\text { Net Income } \\
\text { (USD 000,000) }\end{array} \\
14,273,364.41\end{array}$} & \multirow{2}{*}{$\begin{array}{c}\begin{array}{c}\text { FCFF } \\
\text { (USD 000,000) }\end{array} \\
(413,600,000) \\
42,108,644\end{array}$} & \multirow{2}{*}{$\begin{array}{c}\begin{array}{c}\text { Discounted FCFF } \\
\text { (USD 000) }\end{array} \\
39,313,458\end{array}$} & \multirow{2}{*}{$\begin{array}{c}\begin{array}{c}\text { FCFE } \\
(U C D D \\
(U 00)\end{array} \\
(165,440,000) \\
20,689,360\end{array}$} & \multirow{2}{*}{$\begin{array}{c}\begin{array}{c}\text { Discounted FCFE } \\
\text { (USD 000) }\end{array} \\
18,246,596.84\end{array}$} & & \\
\hline 2022 & Year 1 & & & & & & & & & & & & & & & & $20,689.360$ & $18,246,596.84$ \\
\hline 2023 & Year 2 & $27,852,638.54$ & $378,027,285$ & $56 \%$ & $44 \%$ & $7.37 \%$ & $13.39 \%$ & $7.53 \%$ & $-0.2 \%$ & $(530,591.95)$ & $7.11 \%$ & $14,840,199.48$ & $41,19,699$ & $36,539,123$ & $20,365,454$ & $15,840,312.36$ & $20,365,454$ & $15,840,312.36$ \\
\hline 2024 & Year 3 & $27,684,369.50$ & $360,684,788$ & $52 \%$ & $48 \%$ & $7.68 \%$ & $13.39 \%$ & $7.97 \%$ & $-0.3 \%$ & $(834,691.99)$ & $7.11 \%$ & $15,429,141.11$ & $41,723,386$ & $33,953,886$ & $20,028,916$ & $13,739,214.66$ & $20,028,916$ & $13,739,214.66$ \\
\hline 2025 & Year 4 & 27,509,537.97 & $342,665,933$ & $47 \%$ & $53 \%$ & $8.03 \%$ & $13.39 \%$ & $8.42 \%$ & $-0.4 \%$ & $(972,747.55)$ & $7.11 \%$ & $16,041,051.47$ & $41,519,415$ & $31,545,045$ & $19,679,253$ & $11,905,506.92$ & $19,679,253$ & $11,905,506.92$ \\
\hline 2026 & Year 5 & $27,327,888.01$ & $323,944,343$ & $43 \%$ & $57 \%$ & $8.44 \%$ & $13.39 \%$ & $8.89 \%$ & $-0.5 \%$ & $(964,127.80)$ & $7.11 \% \mathrm{~s}$ & $16,676,826.34$ & $41,307,490$ & $29,300,748$ & $19,315,953$ & $10,306,002.52$ & $19,315,953$ & $10,306,002.52$ \\
\hline 2027 & Year 6 & $27,139,153.70$ & $304,492,610$ & $38 \%$ & $62 \%$ & $8.91 \%$ & $13.39 \%$ & $9.38 \%$ & $-0.5 \%$ & $(832,780.52)$ & $7.11 \%$ & $17,337,396.42$ & $41,087,300$ & $27,209,934$ & $18,938,485$ & $8,911,568.40$ & $18,938,485$ & $8,911,568.40$ \\
\hline 2028 & Year 7 & $26,943,058.76$ & $284,282,261$ & $33 \%$ & $67 \%$ & $9.48 \%$ & $13.39 \%$ & $9.89 \%$ & $-0.4 \%$ & $(605,984.43)$ & $7.11 \%$ & $18,023,728.73$ & $40,858,523$ & $25,262,279$ & $18,546,295$ & $7,696,633.08$ & $18,546,295$ & $7,696,635.08$ \\
\hline 2029 & Year 8 & $26,739,316.10$ & $263,283,707$ & $28 \%$ & $72 \%$ & $10.16 \%$ & $13.39 \%$ & $10.42 \%$ & $0 \%$ & $(312,870.50)$ & $7.11 \%$ & $18,736,828.01$ & $40,620,823$ & $23,448,149$ & $18,138,809$ & $6,638,765.63$ & $18,138,809$ & $6,638,765.63$ \\
\hline 2030 & Year 9 & $26,527,627.49$ & $241,466,210$ & $23 \%$ & $77 \%$ & $10.99 \%$ & $13.39 \%$ & $10.97 \%$ & $0 \%$ & $17,190.45$ & $7.11 \% \mathrm{~g}$ & $19,477,738.16$ & $40,373,853$ & $21,758,554$ & $17,715,432$ & $5,718,276.24$ & $17,715,432$ & $5,718,276.24$ \\
\hline 2031 & Year 10 & $26,307,683.02$ & $218,797,831$ & $18 \%$ & $82 \%$ & $12.02 \%$ & $13.39 \%$ & $11.54 \%$ & $0 \%$ & $356,217.16$ & $7.11 \% 10$ & $20,247,543.80$ & $40,117,251$ & $20,185,103$ & $17,275,543$ & $4,917,902.48$ & $17,275,543$ & $4,917,902.48$ \\
\hline 2032 & Year 11 & $26,079.160 .72$ & 1952245385 & $12 \%$ & $88 \%$ & $13.36 \%$ & $13.39 \%$ & $12.13 \%$ & $1 \%$ & 679.188 .03 & $7.11 \% 11$ & 210407373186 & 39850,042 & $\begin{array}{l}18.719968 \\
187968\end{array}$ & 16818499 & $4,4222505.69$ & 16818499 & $4,222505.69$ \\
\hline 2033 & Year 12 & $25,841,726.04$ & $\begin{array}{r}-170,774,393 \\
\end{array}$ & $6 \%$ & $94 \%$ & $-15.13 \%$ & $13.39 \%$ & $12.75 \%$ & $2 \%$ & $965,078.38$ & $7.11 \%$ & $21,878,393.22$ & $39,573,635$ & $17,355,843$ & $\begin{array}{l}-36,343,629 \\
-16\end{array}$ & $\begin{array}{l}3,618,814,67 \\
-1\end{array}$ & $16,343,629$ & $3,618,814.67$ \\
\hline 2034 & Year 13 & $25,595,031.42$ & $171,637,824$ & $0 \%$ & $100 \%$ & $14.91 \%$ & $13.39 \%$ & $13.39 \%$ & $2 \%$ & $511,045.20$ & $7.11 \%$ & $22,741,824,41$ & $39,285,824$ & $16,085,909$ & $42,139,031$ & $228,813.31$ & $42,139,031$ & $8,222,813.31$ \\
\hline 2035 & Year 14 & $25,595,031.42$ & $171,637,824$ & $0 \%$ & $100 \%$ & $14.91 \%$ & $13.39 \%$ & $13.39 \%$ & $2 \%$ & $450,706.83$ & $7.11 \% 14$ & $22,741,824.41$ & $39,285,824$ & $15,018,121$ & $42,139,031$ & $7,257,249.09$ & $42,139,031$ & $7,257,249.09$ \\
\hline 2036 & Year 15 & $25,595,031.42$ & $171,637,824$ & $0 \%$ & $100 \%$ & $14.91 \%$ & $13.39 \%$ & $13.39 \%$ & $2 \%$ & $397,492.52$ & $7.11 \% 15$ & $22,741,824.41$ & $39,285,824$ & $14,021,213$ & $42,139,031$ & $6,400,396.07$ & $42,139,031$ & $6,400,396.07$ \\
\hline 2037 & Year 16 & $25,595,031.42$ & $171,637,824$ & $0 \%$ & $100 \%$ & $14.91 \%$ & $13.39 \%$ & $13.39 \%$ & $2 \%$ & $350,561.14$ & $7.11 \% 16$ & 22,741,824.41 & $39,285,824$ & $13,090,480$ & $42,139,031$ & $5,644,710.46$ & $42,139,031$ & $5,644,710.46$ \\
\hline 2038 & Year 17 & $25,595,031.42$ & $171,637,824$ & $0 \%$ & $100 \%$ & $14.91 \%$ & $13.39 \%$ & $13.39 \%$ & $2 \%$ & $309,170.89$ & $7.11 \% 17$ & 22,741,824.41 & $39,285,824$ & $12,221,529$ & $42,139,031$ & $4,978,247.56$ & $42,139,031$ & $4,978,247.56$ \\
\hline 2039 & Year 18 & $25,595,031.42$ & $171,637,824$ & $0 \%$ & $100 \%$ & $14.91 \%$ & $13.39 \%$ & $13.39 \%$ & $2 \%$ & $272,667.53$ & $7.11 \% 18$ & $22,741,824,41$ & $39,285,824$ & $11,410,260$ & $42,139,031$ & $4,390,472.99$ & $42,139,031$ & $4,390,472.99$ \\
\hline 2040 & Year 19 & $25,595,031.42$ & $171,637,824$ & $0 \%$ & $100 \%$ & $14.91 \%$ & $13.39 \%$ & $13.39 \%$ & $2 \%$ & 240,474 & $7.11 \% 19$ & 22,741,824.41 & $39,285,824$ & $10,652,842$ & $42,139,031$ & $3,872,096.12$ & $42,139,031$ & $3,872,096.12$ \\
\hline 2041 & Year 20 & $25,595,031.42$ & $171,637,824$ & $0 \%$ & $100 \%$ & $14.91 \%$ & $13.39 \%$ & $13.39 \%$ & $2 \%$ & 212,081 & $7.11 \% 20$ & $22,741,824,41$ & $39,285,824$ & $9,945,7$ & $42,139,031$ & & $42,139,031$ & \\
\hline 2042 & Year 21 & $25,595,031.42$ & $171,637,824$ & $0 \%$ & $100 \%$ & $14.91 \%$ & $13.39 \%$ & $13.39 \%$ & $2 \%$ & $187,041.46$ & $7.11 \% 21$ & $22,741,824,41$ & $39,285,824$ & 9,285, & $42,139,031$ & 8.16 & 0,031 & \\
\hline 2043 & Year 22 & $25,595,031.42$ & $171,637,824$ & $0 \%$ & $100 \%$ & $14.91 \%$ & $13.39 \%$ & $13.39 \%$ & $2 \%$ & 164,95 & $7.11 \% 22$ & 22,741 & $39,285,824$ & 8, & & & 031 & $2,656,137.72$ \\
\hline 2044 & Year 23 & $25,595,031.42$ & $171,637,824$ & $0 \%$ & $100 \%$ & & $13.39 \%$ & $13.39 \%$ & $2 \%$ & & $7.11 \% 23$ & 22,741, & 39,28 & 8,09 & 42,13 & & & \\
\hline 2045 & $\begin{array}{l}\text { Year } 24 \\
\text { S }\end{array}$ & $\begin{array}{l}25,595,031.42 \\
251.42\end{array}$ & 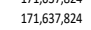 & $0 \%$ & $100 \%$ & & $\begin{array}{l}13.39 \% \\
13.3 \%\end{array}$ & $\begin{array}{l}13.39 \% \\
13.3 \%\end{array}$ & $2 \%$ & & $7.11 \% 24$ & & & & & & & \\
\hline 2046 & Year 25 & $\begin{array}{l}25,53,595,031.41 .42 \\
2.52\end{array}$ & $\begin{array}{l}17,1303,1,2024 \\
171,637,824\end{array}$ & $0 \%$ & $100 \%$ & $\begin{array}{l}149.91 \% \\
149 \%\end{array}$ & $\begin{array}{l}1353510 \\
13.39 \%\end{array}$ & $\begin{array}{l}13.35 \% \\
13.39 \% \\
\end{array}$ & $2 \%$ & $\begin{array}{l}12,0,34.05 \\
113,155.89\end{array}$ & $7.11 \% 25$ & $\begin{array}{r}42,14,1,244,41 \\
5 \quad 22,74,824,41 \\
\end{array}$ & $\begin{array}{l}39,202,0204 \\
39,285,824 \\
\end{array}$ & $\begin{array}{l}7,303,400 \\
7,054,811\end{array}$ & $\begin{array}{l}4,230,39031 \\
42,139,031 \\
\end{array}$ & $\begin{array}{l}2,000,3252.02 \\
1,822,028.01\end{array}$ & $\begin{array}{l}42,130,139011 \\
42,139,031\end{array}$ & $\begin{array}{l}2,0,83,52,02.02 \\
1,822,01\end{array}$ \\
\hline \multirow{2}{*}{\multicolumn{2}{|c|}{ Average }} & $26,268,086.39$ & $228,387,011$ & $17 \%$ & $83 \%$ & $17 \%$ & $13.39 \%$ & 11.64\% & $1 \%$ & $400,367.47$ & & $20,386,132.02$ & $1,001,776,380.29$ & $467,697,667.89$ & $771,663,036.93$ & $6,713,8995.50$ & $771,663,036.93$ & $167,847,387.62$ \\
\hline \multirow{2}{*}{\multicolumn{2}{|c|}{$\begin{array}{l}\text { NPV Project } \\
\text { NPV Equity }\end{array}$}} & $54,097,667.89$ & & & & & & & & & & & & & & & & \\
\hline & & & & & & & & & & & & & & & & & & \\
\hline \multicolumn{2}{|c|}{$\begin{array}{c}\text { NPV Equity } \\
\text { EVA }\end{array}$} & & & & & & & & & & & & & & & & & \\
\hline & & & & & & & & & & & & & & & & & & \\
\hline & & & & & & & & & & & & & & & & & & \\
\hline
\end{tabular}

Figure 3.1 NOPAT and EVA Result of Kaltim 5 Project

Source: Author's Compilation

Figure 3.1 explain about the calculation of NOPAT of Kaltim 5 Project which generated from operating profit after tax, Debt to Equity ratio are on average $17: 83$ along the project life due to the magnitude of the diminishing of the debt portion in capital structure although the beginning of the period the DER is $60: 40$ because EVA calculated the real outstanding of composition for debt to equity at the time of valuation and a slight different to calculation of NPV on Project in order to application of beginning DER for lifetime of cash flow to project. Kaltim 5 project generate positive EVA equals to US\$ 0.4 million parallel with positive NPV equals to US\$ 54.08 million.

\begin{tabular}{|c|c|c|c|c|c|c|c|c|c|c|c|}
\hline \multicolumn{2}{|c|}{ OPERATING YEAR } & \multirow{2}{*}{$\begin{array}{c}\begin{array}{c}\text { NOPAT } \\
\text { (USD 000) }\end{array} \\
47,096,044.66\end{array}$} & \multirow{2}{*}{$\begin{array}{c}\begin{array}{c}\text { Total Invested } \\
\text { Capital } \\
\text { (USD 000,000) }\end{array} \\
612,653,590\end{array}$} & \multirow{2}{*}{$\begin{array}{r}\begin{array}{c}\text { Total Invested } \\
\text { Capital } \\
\text { (USD 000,000) }\end{array} \\
644,164,198\end{array}$} & \multirow{2}{*}{$\begin{array}{l}\begin{array}{l}\text { Debt } \\
\text { Ratio } \\
\text { (\%) }\end{array} \\
60 \%\end{array}$} & \multirow{2}{*}{$\begin{array}{l}\text { Equity } \\
\text { Ratio } \\
\text { (\%) }\end{array}$} & \multirow{2}{*}{$\begin{array}{c}\begin{array}{c}\text { ROIC } \\
(\%)\end{array} \\
7.31 \% \\
\end{array}$} & \multirow{2}{*}{$\begin{array}{c}\begin{array}{c}\text { Cost of } \\
\text { Equity } \\
\text { (\%) }\end{array} \\
13.39 \%\end{array}$} & \multirow{2}{*}{$\begin{array}{c}\begin{array}{c}\text { WACC } \\
(\%)\end{array} \\
7.11 \%\end{array}$} & \multirow{2}{*}{$\begin{array}{l}\text { EVA } \\
(\%)\end{array}$} & \multirow{2}{*}{$\begin{array}{c}\begin{array}{c}\text { Discounted EVA } \\
\text { (USD 000) }\end{array} \\
1,209,943.21\end{array}$} \\
\hline 2022 & Year 1 & & & & & & & & & & \\
\hline 2023 & Year 2 & $46,835,242.45$ & $584,861,438$ & $617,154,452$ & $56 \%$ & $44 \%$ & $7.59 \%$ & $13.39 \%$ & $7.53 \%$ & $0.1 \%$ & $313,403.00$ \\
\hline 2024 & Year 3 & $46,564,268.96$ & $555,985,391$ & $589,091,326$ & $52 \%$ & $48 \%$ & $7.90 \%$ & $13.39 \%$ & $7.97 \%$ & $-0.1 \%$ & $(291,755.57)$ \\
\hline 2025 & Year 4 & $46,282,727.51$ & $525,983,178$ & $559,933,738$ & $47 \%$ & $53 \%$ & $8.27 \%$ & $13.39 \%$ & $8.42 \%$ & $-0.2 \%$ & $(626,474.73)$ \\
\hline 2026 & Year 5 & $45,990,205.94$ & $494,810,880$ & $529,639,004$ & $43 \%$ & $57 \%$ & $8.68 \%$ & $13.39 \%$ & $8.89 \%$ & $-0.2 \%$ & $(720,695.43)$ \\
\hline 2027 & Year 6 & $45,686,276.02$ & $462,422,861$ & $498,162,775$ & $38 \%$ & $62 \%$ & $9.17 \%$ & $13.39 \%$ & $9.38 \%$ & $-0.2 \%$ & $(611,870.83)$ \\
\hline 2028 & Year 7 & $45,370,492.84$ & $428,771,710$ & $465,458,973$ & $33 \%$ & $67 \%$ & $9.75 \%$ & $13.39 \%$ & $9.89 \%$ & $-0.1 \%$ & $(342,988.43)$ \\
\hline 2029 & Year 8 & $45,042,394.12$ & $393,808,164$ & $431,479,723$ & $28 \%$ & $72 \%$ & $10.44 \%$ & $13.39 \%$ & $10.42 \%$ & $0 \%$ & $39,786.90$ \\
\hline 2030 & Year 9 & $44,701,499.55$ & $357,481,040$ & $396,175,283$ & $23 \%$ & $77 \%$ & $11.28 \%$ & $13.39 \%$ & $10.97 \%$ & $0 \%$ & $489,693.77$ \\
\hline 2031 & Year 10 & $44,347,310.08$ & $319,737,157$ & $359,493,969$ & $18 \%$ & $82 \%$ & $12.34 \%$ & $13.39 \%$ & $11.54 \%$ & $1 \%$ & $961,992.00$ \\
\hline 2032 & Year 11 & $43,979,307.23$ & $280,521,264$ & $321,382,084$ & $12 \%$ & $88 \%$ & $13.68 \%$ & $13.39 \%$ & $.12 .13 \%$ & $2 \%$ & $\begin{array}{r}1,416,414.05 \\
-1\end{array}$ \\
\hline 2033 & Year 12 & $43,596,952.27$ & $239,775,950$ & $281,783,835$ & $6 \%$ & $94 \%$ & $15.47 \%$ & $13.39 \%$ & $12.75 \%$ & $3 \%$ & $1,819,250.83$ \\
\hline 2034 & Year 13 & $43,199,685.46$ & $239,775,950$ & $282,975,636$ & $0 \%$ & $100 \%$ & $15.27 \%$ & $13.39 \%$ & $13.39 \%$ & $2 \%$ & $1,038,159.20$ \\
\hline 2035 & Year 14 & $43,199,685.46$ & $239,775,950$ & $282,975,636$ & $0 \%$ & $100 \%$ & $15.27 \%$ & $13.39 \%$ & $13.39 \%$ & $2 \%$ & $915,585.23$ \\
\hline 2036 & Year 15 & $43,199,685.46$ & $239,775,950$ & $282,975,636$ & $0 \%$ & $100 \%$ & $15.27 \%$ & $13.39 \%$ & $13.39 \%$ & $2 \%$ & $807,483.39$ \\
\hline 2037 & Year 16 & $43,199,685.46$ & $239,775,950$ & $282,975,636$ & $0 \%$ & $100 \%$ & $15.27 \%$ & $13.39 \%$ & $13.39 \%$ & $2 \%$ & 712,144.98 \\
\hline 2038 & Year 17 & $43,199,685.46$ & $239,775,950$ & $282,975,636$ & $0 \%$ & $100 \%$ & $15.27 \%$ & $13.39 \%$ & $13.39 \%$ & $2 \%$ & $628,063.04$ \\
\hline 2039 & Year 18 & $43,199,685.46$ & $239,775,950$ & $282,975,636$ & $0 \%$ & $100 \%$ & $15.27 \%$ & $13.39 \%$ & $13.39 \%$ & $2 \%$ & $553,908.53$ \\
\hline 2040 & Year 19 & $43,199,685.46$ & 239,775,950 & $282,975,636$ & $0 \%$ & $100 \%$ & $15.27 \%$ & $\begin{array}{l}13.39 \% \\
\end{array}$ & $13.39 \%$ & $2 \%$ & $488,509.35$ \\
\hline 2041 & Year 20 & $43,199,685.46$ & $239,775,950$ & $282,975,636$ & $0 \%$ & $100 \%$ & $15.27 \%$ & $13.39 \%$ & $13.39 \%$ & $2 \%$ & $430,831.75$ \\
\hline \multicolumn{2}{|c|}{ Average } & $44,554,510.27$ & $358,751,011$ & $397,886,222$ & $21 \%$ & $79 \%$ & $21 \%$ & $13.39 \%$ & $11.20 \%$ & $1 \%$ & $9,231,384.22$ \\
\hline \multirow{2}{*}{\multicolumn{2}{|c|}{$\begin{array}{l}\text { NPV Project } \\
\text { NPV Equity }\end{array}$}} & $87,419,625.66$ & & & & & & & & & \\
\hline & & $(1,675,337.09)$ & & & & & & & & & \\
\hline & & & & & & & & & & \\
\hline \multicolumn{2}{|c|}{$\begin{array}{l}\text { IRR Project } \\
\text { IRR Equity }\end{array}$} & $\begin{array}{r}8.78 \% \\
1.30 \%\end{array}$ & & & & & & & & & \\
\hline
\end{tabular}

\begin{tabular}{|c|c|c|c|c|c|}
\hline WACC & $\begin{array}{l}\text { Net Income } \\
\text { (USD 000,000) }\end{array}$ & $\begin{array}{c}\text { FCFF } \\
\text { (USD 000,000) }\end{array}$ & $\begin{array}{l}\text { Discounted FCFF } \\
\text { (USD 000) }\end{array}$ & $\begin{array}{c}\text { FCFE } \\
\text { (USD 000) }\end{array}$ & $\begin{array}{l}\text { Discounted FCFE } \\
\text { (USD 000) }\end{array}$ \\
\hline & & $(666,044,306)$ & & $\frac{(266,417,723)}{1}$ & \\
\hline $7.11 \%$ & $31,510,608$ & $73,737,817$ & $68,843,074$ & $35,299,795$ & $31,131,999$ \\
\hline $7.11 \%$ & $32,293,014$ & $73,477,015$ & $64,045,919$ & $34,778,191$ & $27,050,583$ \\
\hline $7.11 \%$ & $33,105,935$ & $73,206,041$ & $59,574,014$ & $34,236,244$ & $23,485,000$ \\
\hline $7.11 \%$ & $33,950,559$ & $72,924,500$ & $55,405,564$ & $33,673,161$ & $20,371,508$ \\
\hline $7.11 \%$ & $34,828,124$ & 72,631,978 & $51,520,228$ & $33,088,118$ & $17,654,124$ \\
\hline $7.11 \%$ & $35,739,914$ & $72,328,048$ & $47,899,020$ & $32,480,258$ & $15,283,696$ \\
\hline $7.11 \%$ & $36,687,263$ & $72,012,265$ & $44,524,222$ & $31,848,692$ & $13,217,075$ \\
\hline $7.11 \%$ & $37,671,559$ & $71,684,166$ & $41,379,295$ & $31,192,494$ & $11,416,387$ \\
\hline $7.11 \%$ & $38,694,243$ & $71,343,272$ & $38,448,805$ & $30,510,705$ & $9,848,399$ \\
\hline $7.11 \% 1$ & $\begin{array}{l}39,756,812 \\
3\end{array}$ & $70,989,082$ & $35,718,348$ & $29,802,326$ & $8,483,955$ \\
\hline $7.11 \% 1$ & $40,860,820$ & $70,621,079$ & $33,174,481$ & $29,066,321$ & $7,297,483$ \\
\hline $7.11 \% 1$ & $42,007,885$ & $70,238,725$ & $30,804,658$ & $28,301,611$ & $6,266,557$ \\
\hline $7.11 \% 1$ & $43,199,685$ & $69,841,458$ & $28,597,169$ & $6,841,458$ & $13,638,480$ \\
\hline $7.11 \% 1$ & $43,199,685$ & $69,841,458$ & $26,698,879$ & $69,841,458$ & $12,028,204$ \\
\hline $7.11 \% 1$ & $43,199,685$ & $69,841,458$ & $24,926,598$ & $69,841,458$ & $10,608,051$ \\
\hline $7.11 \% 1$ & $43,199,685$ & $69,841,458$ & $23,271,961$ & $69,841,458$ & $9,355,574$ \\
\hline $7.11 \% 1$ & $43,199,685$ & $69,841,458$ & $21,727,160$ & $69,841,458$ & $8,250,974$ \\
\hline $7.11 \% 1$ & $43,199,685$ & $69,841,458$ & $20,284,904$ & $69,841,458$ & $7,276,794$ \\
\hline \multirow{3}{*}{$7.11 \% 20$} & $43,199,685$ & $69,841,458$ & $18,938,384$ & $69,841,458$ & 6,417,633 \\
\hline & $43,199,685$ & $69,841,458$ & $17,681,248$ & $69,841,458$ & $5,659,912$ \\
\hline & $39,135,211.05$ & $1,423,925,650.48$ & $753,463,932.07$ & $943,009,578.40$ & $13,237,119.27$ \\
\hline
\end{tabular}

Figure 3.1.1 NOPAT and EVA Result of Jawa 3

Source: Author's Compilation 
Figure 3.1.1 explain about that Jawa-3 Project generate positive EVA equals to US\$ 9.32 million along with the positive NPV Project and IRR Project because it is higher than WACC, but NPV on Equity generate negative value because of the IRR on Equity lower than IRR on Equity. It is a slight contradicting to positive value of EVA.

\begin{tabular}{|c|c|c|c|c|c|c|c|c|c|c|c|c|c|c|c|c|c|c|c|}
\hline \multicolumn{12}{|c|}{ EVA Calculation } & \multicolumn{6}{|c|}{ NPVIRR Calculation } & \multirow[b]{2}{*}{$\begin{array}{c}\text { FCFE } \\
(\text { USD 000,000) }\end{array}$} & \multirow[b]{2}{*}{$\begin{array}{c}\text { Discounted CFFE } \\
\text { (USD 000) }\end{array}$} \\
\hline \multicolumn{2}{|c|}{ OPERATING YEAR } & $\begin{array}{l}\text { NOPAT } \\
\text { (USD 000) }\end{array}$ & $\begin{array}{l}\text { Total I Invested } \\
\text { Capital } \\
\text { (USD 000, 000) }\end{array}$ & $\begin{array}{l}\text { Total Invested } \\
\text { Capital } \\
(\text { USD } 000,000)\end{array}$ & $\begin{array}{l}\text { Debt } \\
\text { Ratio }\end{array}$ & $\begin{array}{l}\text { Equity } \\
\text { Ratio }\end{array}$ & $\begin{array}{l}\text { RoIC } \\
(\%)\end{array}$ & $\begin{array}{l}\text { Cost of } \\
\text { Equity } \\
\text { (\%) }\end{array}$ & $\begin{array}{c}\text { wacc } \\
(\%)\end{array}$ & $\begin{array}{l}E V A \\
(\%)\end{array}$ & $\begin{array}{l}\text { Discounted EVA } \\
\text { (USD 000) }\end{array}$ & WACC & $\begin{array}{l}\text { Net tncome } \\
\text { (USD 000,000) }\end{array}$ & $\begin{array}{c}\text { FCFF } \\
\text { (USD 000,000) }\end{array}$ & $\begin{array}{l}\text { Discounted FCFF } \\
\text { (USD 000) }\end{array}$ & $\begin{array}{l}\text { FCFE } \\
\text { (USD 000) }\end{array}$ & $\begin{array}{l}\text { Discounted FCFE } \\
\text { (USD 000) }\end{array}$ & & \\
\hline 2022 & Year 1 & $1,135,30.90$ & $\begin{array}{l}14,768,779 \\
\end{array}$ & 155,528381 & $60 \%$ & $40 \%$ & $7.31 \%$ & $13.39 \%$ & $7.11 \%$ & $0.2 \%$ & $29,167.19$ & & & $\begin{array}{r}(16,055,829) \\
1,777,542\end{array}$ & & $\begin{array}{r}6,422,332) \\
850,946\end{array}$ & 750,476 & & \\
\hline 2023 & Year 2 & $1,129,021.94$ & $14,098,814$ & $14,877,278$ & $56 \%$ & $44 \%$ & $7.59 \%$ & $13.39 \%$ & $7.53 \%$ & $0.1 \%$ & $7,554.97$ & $7.11 \%$ & $\begin{array}{l}753,0033 \\
778,463\end{array}$ & $\begin{array}{l}1,171,742 \\
1,71,255\end{array}$ & $\begin{array}{l}1,1,593,54807 \\
1,9307\end{array}$ & $\begin{array}{l}880,946 \\
838,372\end{array}$ & $\begin{array}{l}70,470 \\
652,088\end{array}$ & $\begin{array}{l}20,86,395600 \\
20,365,454\end{array}$ & 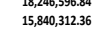 \\
\hline 2024 & Year 3 & $1,122,489.78$ & $13,402,721$ & $14,200,781$ & $52 \%$ & $48 \%$ & $7.90 \%$ & $13.39 \%$ & $7.97 \%$ & $-0.1 \%$ & $(7,033.13)$ & $7.11 \%$ & 798,060 & $1,764,723$ & $1,436,106$ & 825,307 & 566,135 & $20,028,916$ & $13,739,214.66$ \\
\hline 2025 & Year 4 & $1,115,702.88$ & $12,679,481$ & $13,497,901$ & $47 \%$ & $53 \%$ & $8.27 \%$ & $13.39 \%$ & $8.42 \%$ & $-0.2 \%$ & $(15,101.95)$ & $7.11 \%$ & 818,421 & $1,757,936$ & $1,335,620$ & 811,734 & 491,081 & $19,679,253$ & $11,905,506.92$ \\
\hline 2026 & Year 5 & $1,108,651.28$ & $11,928,033$ & $12,767,609$ & $43 \%$ & $57 \%$ & $8.68 \%$ & $13.39 \%$ & $8.89 \%$ & $-0.2 \%$ & $(17,373.26)$ & $7.11 \%$ & 839,575 & $1,750,884$ & $1,241,959$ & 797,630 & 425,575 & $19,315,953$ & $10,306,002.52$ \\
\hline 2027 & Year 6 & $1,101,324.67$ & $11,147,280$ & $12,008,835$ & $38 \%$ & $62 \%$ & $9.17 \%$ & $13.39 \%$ & $9.38 \%$ & $-0.2 \%$ & $(14,749.91)$ & $7.11 \%$ & 861,555 & $1,743,558$ & $1,154,666$ & 782,977 & 368,433 & $18,938,485$ & $8,911,568.40$ \\
\hline 2028 & Year 7 & $1,093,712.32$ & $10,336,077$ & $11,220,469$ & $33 \%$ & $67 \%$ & $9.75 \%$ & $13.39 \%$ & $9.89 \%$ & $-0.1 \%$ & $(8,268.16)$ & $7.11 \%$ & 884,392 & $1,735,945$ & $1,073,312$ & 766,752 & 318,614 & $18,546,295$ & $7,696,635.08$ \\
\hline 2029 & Year 8 & $1,085,803.09$ & $9,993,237$ & $10,401,357$ & $28 \%$ & $72 \%$ & $10.44 \%$ & $13.39 \%$ & $10.42 \%$ & $0 \%$ & 959.11 & $7.11 \%$ & 908,120 & $1,728,036$ & 997,500 & 751,934 & 275,206 & $18,138,809$ & $6,638,765.63$ \\
\hline 2030 & Year 9 & $1,077,585.40$ & $8,617,526$ & $9,550,299$ & $23 \%$ & $77 \%$ & $11.28 \%$ & $13.39 \%$ & $10.97 \%$ & $0 \%$ & $11,804.68$ & $7.11 \%$ & 932,773 & $1,719,819$ & 926,856 & 735,499 & 237,408 & $17,715,432$ & $5,718,276.24$ \\
\hline 2031 & Year 10 & $1,069,047.23$ & $7,707,663$ & $8,666,051$ & $18 \%$ & $82 \%$ & $12.34 \%$ & $13.39 \%$ & $11.54 \%$ & $1 \%$ & $23,190.02$ & $7.11 \% 10$ & 958,388 & $1,711,280$ & 861,035 & 718 & 204,516 & $17,275,543$ & $4,917,902.48$ \\
\hline 2032 & Year 11 & $1,060,176.06$ & $6,762,315$ & $7,747,316$ & $12 \%$ & $88 \%$ & $13.68 \%$ & $13.39 \%$ & $12.13 \%$ & $2 \%$ & $34,144.43$ & $7.11 \%$ & 985,001 & $1,702,409$ & 799,712 & 700,680 & 175,915 & $16,818,499$ & $4,222,505.69$ \\
\hline 2033 & Year 12 & $1,050,958.91$ & $5,780,098$ & $6,792,751$ & $6 \%$ & $94 \%$ & $15.47 \%$ & $13.39 \%$ & $12.75 \%$ & $3 \%$ & $43,855.31$ & $7.11 \%$ & $1,012,652$ & $1,693,192$ & 742,585 & 682,246 & 151,063 & $16,343,629$ & $3,618,814.67$ \\
\hline 2034 & Year 13 & $1,041,382.30$ & $5,780,098$ & $6,821,481$ & $0 \%$ & $100 \%$ & $15.27 \%$ & $13.39 \%$ & $13.39 \%$ & $2 \%$ & $25,026.12$ & $7.11 \%$ & $\begin{array}{l}1,041,382 \\
-\end{array}$ & $1,683,615$ & & $1,683,615$ & 328,773 & $42,139,031$ & $8,228,813.31$ \\
\hline 2035 & Year 14 & $1,041,382$ & & & $0 \%$ & $100 \%$ & & & & $2 \%$ & & $7.11 \% 14$ & $\begin{array}{l}1,041,382 \\
1\end{array}$ & & & $1,683,615$ & 289,955 & $42,139,031$ & $7,257,249.09$ \\
\hline 2036 & Year 15 & $1,041,382.30$ & $5,780,098$ & $6,821,481$ & $0 \%$ & $100 \%$ & $15.27 \%$ & $13.39 \%$ & $13.39 \%$ & $2 \%$ & 19,46 & $7.11 \%$ & $\begin{array}{l}1,041,382 \\
1\end{array}$ & $1,683,615$ & 600,8 & $1,683,615$ & 255,720 & $42,139,031$ & $6,400,396.07$ \\
\hline 2037 & Year 16 & $1,041,382.30$ & $5,780,098$ & $6,821,481$ & $0 \%$ & $100 \%$ & $15.27 \%$ & $13.39 \%$ & $13.39 \%$ & $2 \%$ & $\begin{array}{l}17,167.14 \\
\end{array}$ & $7.11 \%$ & $\begin{array}{l}1,041,382 \\
1\end{array}$ & $1,683,615$ & 561,000 & $1,683,615$ & 225,528 & $42,139,031$ & $5,644,710.46$ \\
\hline 2038 & Year 17 & $1,041,382.30$ & $5,780,098$ & $6,821,481$ & $0 \%$ & $100 \%$ & $15.27 \%$ & $13.39 \%$ & $13.39 \%$ & $2 \%$ & $15,140.24$ & $7.11 \% 17$ & ${ }_{1.1041,382}$ & $\begin{array}{l}1,683,615 \\
\text {. }\end{array}$ & 523,760 & $1,1683,615$ & 198,900 & $\begin{array}{l}42,139,031 \\
4\end{array}$ & $\begin{array}{l}4,978,247.56 \\
4\end{array}$ \\
\hline 2039 & Year 18 & $\begin{array}{l}1,041,382.30 \\
1,250\end{array}$ & $\begin{array}{l}5,780,098 \\
5,030\end{array}$ & $6,821,481$ & $0 \%$ & $100 \%$ & $15.27 \%$ & $13.39 \%$ & $13.39 \%$ & $2 \%$ & $13,352.66$ & $7.11 \% 18$ & $\begin{array}{l}1,041,382 \\
1,32\end{array}$ & 1, $1,683,615$ & 488,993 & $1,683,615$ & 175,416 & $42,139,031$ & $4,390,472.99$ \\
\hline 2040 & Year 19 & $1,041,382.30$ & $5,780,098$ & $\begin{array}{l}6.821481 \\
\end{array}$ & $0 \%$ & $100 \%$ & $15.27 \%$ & $13.39 \%$ & $13.39 \%$ & $2 \%$ & ${ }_{11,776.13}^{13}$ & $7.11 \%$ 19 & ${ }_{1.041,382}^{1.04}$ & $\begin{array}{l}1,683,615 \\
\text {. }\end{array}$ & 456,533 & $1,1683,615$ & 154,705 & $\begin{array}{l}42,139,031 \\
4\end{array}$ & $\begin{array}{l}3,872,0,096.12 \\
3\end{array}$ \\
\hline 2041 & $\begin{array}{l}\text { rear } 19 \\
\text { Year } 20\end{array}$ & $\begin{array}{l}1,144,1,383.30 \\
1,041,32.30\end{array}$ & $\begin{array}{l}5,880,098 \\
5,780,098\end{array}$ & $\begin{array}{l}6,821,481 \\
6,821,481\end{array}$ & $0 \%$ & $100 \%$ & $\begin{array}{l}15.27 \% \\
15 \%\end{array}$ & $\begin{array}{l}13.35 \% \\
13.3 \% \%\end{array}$ & $\begin{array}{l}13.35 \% \\
13.39 \%\end{array}$ & $2 \%$ & $\begin{array}{l}11,76.13 \\
10,385.74\end{array}$ & $\begin{array}{l}7.111 \% \\
7.11 \% 20\end{array}$ & $\begin{array}{l}1,144,1,182 \\
1,04,382\end{array}$ & $\begin{array}{l}1,038,615 \\
1,683,615\end{array}$ & $\begin{array}{l}450,533 \\
426,229 \\
\end{array}$ & $\begin{array}{l}1,863,5015 \\
1,683,615\end{array}$ & $\begin{array}{l}134,405 \\
136,439 \\
\end{array}$ & $\begin{array}{l}4,213,1931 \\
42,139,031\end{array}$ & $\begin{array}{l}3,812,060.12 \\
3,414,923.27\end{array}$ \\
\hline \multicolumn{2}{|c|}{ Average } & $\begin{array}{l}1,1,074,04252.04 \\
\end{array}$ & $8,8,648,141$ & $9,0251,1,544$ & $21 \%$ & $799 \%$ & $21 \%$ & $13.39 \%$ & $11.20 \%$ & $1 \%$ & $222,534.03$ & & $943,403.08$ & $34,325,503.91$ & $18,163,187.90$ & $22,732,422.13$ & $319,097.27$ & $360,967,879.84$ & $155,949,010.36$ \\
\hline \multicolumn{2}{|c|}{$\begin{array}{l}\text { NPV Project } \\
\text { PV F }\end{array}$} & $2,107,359.12$ & & & & & & & & & & & & & & & & & \\
\hline \multirow{2}{*}{\multicolumn{2}{|c|}{$\begin{array}{c}\text { NPVE Equity } \\
\text { EVA }\end{array}$}} & $\begin{array}{l}(40,386.09) \\
0\end{array}$ & & & & & & & & & & & & & & & & & \\
\hline & & $222,534.03$ & & & & & & & & & & & & & & & & & \\
\hline \multicolumn{2}{|c|}{ IRR Proj } & $\begin{array}{l}8.78 \% \\
13.3 \% \%\end{array}$ & & & & & & & & & & & & & & & & & \\
\hline
\end{tabular}

Figure 3.1.2 NOPAT and EVA Result of Manokwari 2

Source: Author's Compilation

Figure 3.1.2 explain about that Manokwari 2 generate positive EVA equals to US\$ 0.22 million along with positive NPV and IRR Project because it is higher than WACC along the negative NPV and IRR lower than WACC, but this project has the same issue with Jawa-3 project that has a negative cash flow to equity.

NPV to Project or Equity has a different calculation to EVA calculation, NPV to Project and Equity are the today valuation, a serial cash flow happened in the future discounted with today discount rate using WACC and Cost of equity and after that it compared to initial outlay but EVA valuation does not compare to initial outlay, it only describes the condition at certain time to check the value added that be given to capital investor.

\subsection{ROIC Analysis}

Earlier result in NOPAT and EVA Analysis directly stated that if ROIC is higher than WACC so that the company or project will create a positive EVA regardless the capital structure and the portion of debt and equity. Figure 3.2 will explain the growth of ROIC compared with the growth of EVA of 3 (three) Projects. As we could see in that table that Kaltim-5, jawa-3 and Manokwari-2 on average generate ROIC higher than WACC that means all of those projects get positive EVA as a surplus for the company for creating a bigger profit to cover cost for capital holder. Still, other than that, analyst or investor should get comprehensively point of sight to the EVA calculation. Because there are variables that drive the result of ROIC and also WACC. ROIC could become another additional parameter for investor or project analyst to get another perspective for project's financial aspect to create value to shareholders juxtapose with NPV IRR calculation.

\begin{tabular}{lccccccc}
\hline & \multicolumn{2}{c}{ Kaltim 5 } & \multicolumn{2}{c}{ Jawa 3 } & \multicolumn{2}{c}{ Manokwari 2 } \\
\cline { 2 - 7 } \multicolumn{2}{c}{ Operating Year } & ROIC & WACC & ROIC & WACC & ROIC & WACC \\
\hline 2022 & Year 1 & $\mathbf{7 . 1 0 \%}$ & $7.11 \%$ & $7.31 \%$ & $7.11 \%$ & $7.31 \%$ & $7.11 \%$ \\
2023 & Year 2 & $\mathbf{7 . 3 7 \%}$ & $7.53 \%$ & $7.59 \%$ & $7.53 \%$ & $7.59 \%$ & $7.53 \%$ \\
2024 & Year 3 & $\mathbf{7 . 6 8 \%}$ & $7.97 \%$ & $\mathbf{7 . 9 0 \%}$ & $7.97 \%$ & $\mathbf{7 . 9 0 \%}$ & $7.97 \%$ \\
2025 & Year 4 & $\mathbf{8 . 0 3 \%}$ & $8.42 \%$ & $\mathbf{8 . 2 7 \%}$ & $8.42 \%$ & $\mathbf{8 . 2 7 \%}$ & $8.42 \%$ \\
2026 & Year 5 & $\mathbf{8 . 4 4 \%}$ & $8.89 \%$ & $\mathbf{8 . 6 8 \%}$ & $8.89 \%$ & $\mathbf{8 . 6 8 \%}$ & $8.89 \%$ \\
\hline
\end{tabular}




\begin{tabular}{rrrrrrrr}
\hline & & \multicolumn{2}{c}{ Kaltim 5 } & \multicolumn{2}{c}{ Jawa 3 } & \multicolumn{2}{c}{ Manokwari 2 } \\
\cline { 2 - 7 } Operating Year & ROIC & WACC & ROIC & WACC & ROIC & WACC \\
\hline 2027 & Year 6 & $\mathbf{8 . 9 1 \%}$ & $9.38 \%$ & $\mathbf{9 . 1 7 \%}$ & $9.38 \%$ & $\mathbf{9 . 1 7 \%}$ & $9.38 \%$ \\
2028 & Year 7 & $\mathbf{9 . 4 8 \%}$ & $9.89 \%$ & $\mathbf{9 . 7 5 \%}$ & $9.89 \%$ & $\mathbf{9 . 7 5 \%}$ & $9.89 \%$ \\
2029 & Year 8 & $\mathbf{1 0 . 1 6 \%}$ & $10.42 \%$ & $10.44 \%$ & $10.42 \%$ & $10.44 \%$ & $10.42 \%$ \\
2030 & Year 9 & $\mathbf{1 0 . 9 9 \%}$ & $10.97 \%$ & $\mathbf{1 1 . 2 8 \%}$ & $10.97 \%$ & $11.28 \%$ & $10.97 \%$ \\
2031 & Year 10 & $12.02 \%$ & $11.54 \%$ & $12.34 \%$ & $11.54 \%$ & $12.34 \%$ & $11.54 \%$ \\
2032 & Year 11 & $13.36 \%$ & $12.13 \%$ & $13.68 \%$ & $12.13 \%$ & $13.68 \%$ & $12.13 \%$ \\
2033 & Year 12 & $15.13 \%$ & $12.75 \%$ & $15.47 \%$ & $12.75 \%$ & $15.47 \%$ & $12.75 \%$ \\
2034 & Year 13 & $14.91 \%$ & $13.39 \%$ & $15.27 \%$ & $13.39 \%$ & $15.27 \%$ & $13.39 \%$ \\
2035 & Year 14 & $14.91 \%$ & $13.39 \%$ & $15.27 \%$ & $13.39 \%$ & $15.27 \%$ & $13.39 \%$ \\
2036 & Year 15 & $14.91 \%$ & $13.39 \%$ & $15.27 \%$ & $13.39 \%$ & $15.27 \%$ & $13.39 \%$ \\
2037 & Year 16 & $14.91 \%$ & $13.39 \%$ & $15.27 \%$ & $13.39 \%$ & $15.27 \%$ & $13.39 \%$ \\
2038 & Year 17 & $14.91 \%$ & $13.39 \%$ & $15.27 \%$ & $13.39 \%$ & $15.27 \%$ & $13.39 \%$ \\
2039 & Year 18 & $14.91 \%$ & $13.39 \%$ & $15.27 \%$ & $13.39 \%$ & $15.27 \%$ & $13.39 \%$ \\
2040 & Year 19 & $14.91 \%$ & $13.39 \%$ & $15.27 \%$ & $13.39 \%$ & $15.27 \%$ & $13.39 \%$ \\
2041 & Year 20 & $14.91 \%$ & $13.39 \%$ & $15.27 \%$ & $13.39 \%$ & $15.27 \%$ & $13.39 \%$ \\
2042 & Year 21 & $14.91 \%$ & $13.39 \%$ & & & & \\
2043 & Year 22 & $14.91 \%$ & $13.39 \%$ & & & & \\
2044 & Year 23 & $14.91 \%$ & $13.39 \%$ & & & & \\
2045 & Year 24 & $14.91 \%$ & $13.39 \%$ & & & & \\
2046 & Year 25 & $14.91 \%$ & $13.39 \%$ & & & & \\
& & $\mathbf{1 2 . 5 0 \%}$ & $\mathbf{1 1 . 6 4 \%}$ & $\mathbf{1 2 . 2 0 \%}$ & $\mathbf{1 1 . 2 0 \%}$ & $\mathbf{1 2 . 2 0 \%}$ & $\mathbf{1 1 . 2 0 \%}$ \\
\hline Fig
\end{tabular}

Figure 3.2 ROIC and WACC of Projects

Source: Author's Compilation

\subsection{Solvency Ratio}

The increasing of debt portion in order to minimize the wacc will impact of the level of financial distress when a project or company or business could not make the payment of the interest when the worst condition to come. So, the Interest Coverage Ratio (ICR) for solvency ratio analysis to clearly see the impact of the capital structure that could cause the increasing level of financial distress for all Projects. Figure 3.3 explain the result of the Interest Coverage Ratio and EBIT to Debt Repayment as additional Indicator to strengthen the ICR Ratio. For 3 (three) Projects. On Average, Kaltim-5 and Jawa-3 generate Interest Coverage Ratio 9.47x and 10.28x, it means that operating profit could back up 9 and 10 times more than the interest expense, Manokwari-2 generate ICR 9.91x that means operating profit could back up 9 times more than interest expense. Those results describe the reveal the good value from three projects and good financial strength to cover all interest in those projects.

\begin{tabular}{lcccc}
\hline \multirow{2}{*}{ Operating Year } & \multicolumn{3}{c}{ Interest Coverage Ratio } \\
\cline { 2 - 5 } & & Kaltim 5 & Jawa 3 & Manokwari 2 \\
\hline 2022 & Year 1 & 3.53 & 3.70 & 3.70 \\
2023 & Year 2 & 3.78 & 3.96 & 3.96 \\
2024 & Year 3 & 4.08 & 4.28 & 4.28 \\
2025 & Year 4 & 4.46 & 4.67 & 4.67 \\
2026 & Year 5 & 4.92 & 5.16 & 5.16 \\
2027 & Year 6 & 5.53 & 5.79 & 5.79 \\
2028 & Year 7 & 6.33 & 6.63 & 6.63 \\
2029 & Year 8 & 7.46 & 7.81 & 7.81 \\
2030 & Year 9 & 9.15 & 9.59 & 9.59 \\
2031 & Year 10 & 11.97 & 12.55 & 12.55 \\
2032 & Year 11 & 17.62 & 18.47 & 18.47 \\
2033 & Year 12 & 34.58 & 36.25 & 36.25 \\
& Average & 9.45 & 9.91 & 9.91 \\
\hline
\end{tabular}

Figure 3.3 Interest Coverage Ratio of Projects

Source: Author's Compilation 


\subsection{Sensitivity Analysis}

Sensitivity analysis is known as risk mitigating tools or scenario analysis as an additional measurement to the project by mapping the different condition in order the changes of certain variables that cause impact to the project. This paper takes the boundary of sight to the debt to equity ratio which can cause the profitability of the project, as it mentioned from the previous chapter in general assumption which all projects use $60: 40$ Debt to Equity Ratio in order to ease and equalize the basis of evaluation. Hereafter, in this sensitivity analysis, there are 3 (three) condition of DER that will be shift from the default condition, first, $70: 30$, second $80: 20$ and last $40: 60$. Last condition of sensitivity, it will take a higher portion of equity than debt in order to get the more comprehensive result. Figure 3.4 will explain about the sensitivity that cause to the EVA of the projects which caused from the alteration of WACC and also to the cash flow to the equity of the projects.

\begin{tabular}{|c|c|c|c|c|c|c|c|c|}
\hline & DER 6040 & & DER 70 & & DER 8020 & & DER 4060 & \\
\hline \multirow{6}{*}{ 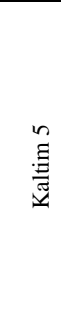 } & NPV Project & $84,966,817.11$ & $\begin{array}{l}\text { NPV } \\
\text { Project }\end{array}$ & $100,573,811.64$ & $\begin{array}{l}\text { NPV } \\
\text { Project }\end{array}$ & $117,899,439.90$ & NPV Project & $58,127,184.57$ \\
\hline & NPV Equity & $2,407,387.62$ & $\begin{array}{l}\text { NPV } \\
\text { Equity }\end{array}$ & $1,158,652.76$ & NPV Equity & $428,699.48$ & NPV Equity & $6,229,596.21$ \\
\hline & EVA & $2,281,398.76)$ & EVA & $13,797,221.47$ & EVA & $29,462,102.32$ & EVA & $(36,005,626)$ \\
\hline & IRR Project & $9.35 \%$ & $\begin{array}{l}\text { IRR } \\
\text { Project }\end{array}$ & $8.78 \%$ & IRR Project & $7.77 \%$ & IRR Project & $10.93 \%$ \\
\hline & IRR Equity & $13.57 \%$ & $\begin{array}{l}\text { IRR } \\
\text { Equity }\end{array}$ & $13.30 \%$ & IRR Equity & $13.44 \%$ & IRR Equity & $13.74 \%$ \\
\hline & ICR Average & $9.91 x$ & $\begin{array}{l}\text { ICR } \\
\text { Average }\end{array}$ & $7.2 \mathrm{x}$ & $\begin{array}{l}\text { ICR } \\
\text { Average }\end{array}$ & $5.53 x$ & ICR Average & $17.44 \mathrm{x}$ \\
\hline \multirow[t]{3}{*}{ Debt } & & $60.00 \%$ & & $70.00 \%$ & & $80.00 \%$ & & $40.00 \%$ \\
\hline & NPV Project & $87,419,625.66$ & $\begin{array}{l}\text { NPV } \\
\text { Project }\end{array}$ & $106,551,064.83$ & $\begin{array}{l}\text { NPV } \\
\text { Project }\end{array}$ & $127,456,139.63$ & NPV Project & $53,769,316.60$ \\
\hline & NPV Equity & $(1,675,337.09)$ & $\begin{array}{l}\text { NPV } \\
\text { Equity }\end{array}$ & $(26,374.28)$ & NPV Equity & $2,380,230.51$ & NPV Equity & $(2,944,901.49)$ \\
\hline \multirow{4}{*}{ 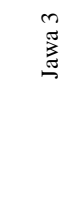 } & EVA & $9,231,384.22$ & EVA & $36,745,884.39$ & EVA & $63,598,707.67$ & EVA & $(47,679,254.66)$ \\
\hline & IRR Project & $8.78 \%$ & $\begin{array}{l}\text { IRR } \\
\text { Project }\end{array}$ & $8.01 \%$ & IRR Project & $7.23 \%$ & IRR Project & $10.34 \%$ \\
\hline & IRR Equity & $13.30 \%$ & $\begin{array}{l}\text { IRR } \\
\text { Equity }\end{array}$ & $13.39 \%$ & IRR Equity & $13.59 \%$ & IRR Equity & $13.27 \%$ \\
\hline & ICR Average & $9.91 x$ & $\begin{array}{l}\text { ICR } \\
\text { Average }\end{array}$ & $7.65 x$ & $\begin{array}{l}\text { ICR } \\
\text { Average }\end{array}$ & $5.99 x$ & ICR Average & $17.88 \mathrm{x}$ \\
\hline \multirow[t]{2}{*}{ Debt } & & $60.00 \%$ & & $70.00 \%$ & & $80.00 \%$ & & $40.00 \%$ \\
\hline & NPV Project & $2,107,359.12$ & $\begin{array}{l}\text { NPV } \\
\text { Project }\end{array}$ & $3,737,741.13$ & $\begin{array}{l}\text { NPV } \\
\text { Project }\end{array}$ & $5,589,448.47$ & NPV Project & $(611,928.89)$ \\
\hline \multirow{5}{*}{ 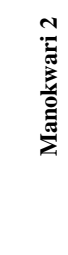 } & NPV Equity & $(40,386.09)$ & $\begin{array}{l}\text { NPV } \\
\text { Equity }\end{array}$ & $702,709.06$ & NPV Equity & $1,445,804.21$ & NPV Equity & $(1,526,576.39)$ \\
\hline & EVA & $222,534.03$ & EVA & $1,631,720.11$ & EVA & $3,050,479.68$ & EVA & $(2,562,425.45)$ \\
\hline & IRR Project & $8.78 \%$ & $\begin{array}{l}\text { IRR } \\
\text { Project }\end{array}$ & $8.85 \%$ & IRR Project & $8.92 \%$ & IRR Project & $8.65 \%$ \\
\hline & IRR Equity & $13.30 \%$ & $\begin{array}{l}\text { IRR } \\
\text { Equity }\end{array}$ & $15.33 \%$ & IRR Equity & $18.75 \%$ & IRR Equity & $10.87 \%$ \\
\hline & ICR Average & $9.91 x$ & $\begin{array}{l}\text { ICR } \\
\text { Average }\end{array}$ & $8.49 \mathrm{x}$ & $\begin{array}{l}\text { ICR } \\
\text { Average }\end{array}$ & $7.42 \mathrm{x}$ & ICR Average & $14.86 \mathrm{x}$ \\
\hline Debt & & $60.00 \%$ & & $70.00 \%$ & & $80.00 \%$ & & $40.00 \%$ \\
\hline
\end{tabular}

Figure 3.4 Sensitivity Analysis

Source: Author's Compilation

Figure 3.4 describe about the result of sensitivity analysis that is caused by the change of capital structure and the effect to EVA result also the result of NPV IRR and Interest Coverage Ratio. From that explanation, it could be derived that the increasing of debt portion contemplating with equity reduction cause the increasing of EVA for all the project, NPV IRR for project Jawa-3 and Manokwari-2 have the same effect toward EVA caused by the increasing of Debt portion but have a slightly different for kaltim-5. It arouses curiosity to scrutinize the effect of NPV or IRR on Equity to EVA. 


\section{Conclusion}

Enormous amount of capital needed in Project in Indonesia could not only fulfilled by the corporate finance but also need specific financing scheme to finance the project, which does not rely on the balance sheet of the company but only in the cash flow produce from the project. Project finance put the greater level of risk for lenders compared with the equity holder due to non-recourse and source of payment. Some Electricity Projects in Indonesia have high Debt to Equity Ratio so that create a curiosity for equity holder in order to get a financial benefit from the project. Economic Value Added become a one of financial indicator to strengthen another commonly used NPV and IRR parameter to reassure the equity holder to still get the benefit or "bonus" from the excess between ROIC and WACC of the project. Project owner could project the value they could get from EVA analysis in the Project in order to protect the capital impairment as a safety margin and to maintain the cost of debt which sufficient to create positive EVA.

PLN as a representative of GOI could become a project owner and project executor. Once become an owner PLN should pay attention to the positive EVA and when become an executor PLN should pay attention to give the lowest tariff to the owner of the project regardless of the value of the EVA. Capital structure does not affect the value of EVA as long as the ROIC of the project has higher value than WACC.

\section{Reference}

Agarwal, Y. (2013). Capital Structure Decisions. Wiley.

Agostini, M. (2018). Corporate Financial Distress. Palgrave Macmillan.

Altman, E., Hotchkiss, E. (2006). Corporate Financial Distress and Banktruptcy. John Wiley and Son.

Anderson, E. (2014). Business Risk Management. Wiley.

Baker, K. (2011). Capital Structure and Corporate Financing Decisions, Wiley.

Boland, L. (2003). The Foundations of Economic Method $2^{\text {nd }}$ Edition. Routledge.

Bragg, S. (2007). Business Ratio and Formulas. Wiley.

Brigham, E., Houston, J. F. (2019). Fundamentals of Financial Management. Cengage.

Calandro. J, Jr. (2009). Applied Value Investing the Practical Application of Benjamin Graham and Warren Buffets Valuation Principle to Acquisition. McGraw-Hill Companies.

Damodaran, A. (2012). Investment Valuation_Tools and Techniques for Determining the Value of The Asset $3^{\text {rd }}$ Edition. Wiley.

Yescombe, E. R. (2013). Principles of Project Finance. Elsevier Inc.

Frankle, M., Larry H. F. (2017). Mergers and Acquisitions Basic. Wiley.

Gatti, S. (2008). Project Finance in Theory and Practice_Designing, Structuring, and Financing Private. Academic Press.

Grant, J. (2003). Foundations of Economic Value-Added $2^{\text {nd }}$. Wiley.

Holland, D., Bryan M. (2008). Beyond Earnings_Applying the HOLT CFROI and Economic Profit Framework. Wiley.

Koller, T., Marc G. (2015). Valuation-Measuring and Managing the Value Companies $6^{\text {th }}$ Edition, Wiley. 
Krishna, P. (2006). Business Analysis and Valuation Using Financial Statement. South Western.

Lessambo, F. (2018). Financial Statements Analysis and Reporting. Springer Nature Switzerland AG.

Mihaljevic, J. (2015). The Manual Ideas of Ideas the Proven Framework for Finding the Best Value Investment, Wiley.

Misrahi, C. (2007). Getting Started in Value Investing. Wiley.

Rao, R., Eric S. (2007). A Theory of Firm's Cost of Capital. World Scientific.

Reuvid, J. (2008). Managing Business Risk. Kogan Page.

Rist, M., Albert, P. (2015). Financial Ratios for Executives. Penhagenco LLC.

Stern, J. (2001). The EVA Chalange Implementing Value Added Change in an Organization. Wiley.

Stewart, B. III. (2013). Best- Practice EVA. Wiley.

Triantis, J. (2018). Project Finance for Business Development. Wiley.

Walsh, C. (2006). Key Management Ratios. Pearson Education. 